\title{
雁木通りの空間構造 \\ SPACE STRUCTURE OF THE GANGI ARCADE
}

菅原邦生*

Kunio SUGAHARA

Passage width changed with places where GangiArcade was built. This is the place of traffic or a trade activity and Gangi Arcade is not only used as a passage for pedestrians, but it is because width was decided according to the use situation under Gangi Arcade.

\section{Keywords: Gangi, Gangi Arcade, Space Structure}

难木 碓木通り 空間構造

\section{I 、はじめに}

碓木は、新潟県とその周辺地域において、主屋から道路側に下ろ した庇を指す呼称である。同様の庇は他県にも見られ、青森・岩手・ 秋田の各県では小店(こみせ)と呼ばれる。

さらに近世文書には、「雁木（長岡・高田ほか）、小見世（弘前・ 久保田ほか)、小閒屋(米沢)」などの呼称が確認できる。

碓木通りは、墚雪地域の歩行者用の通路であり、雁木を設けた町 家が連続することで形成される。近世文書には、「㕍木通り(長岡)、 雪道 (久保田)、小閒屋通り (米沢)」などの呼称が確認できる。

このように雁木および雁木通りは、地域によって呼称が異なるも のの、いずれも歩行者用の通路として利用されることから、本研究 では、䧹木が町並みに連続し、通路機能をもつものを「陮木通り」 と定義する。

これまで雁木通りの形成と衰退について検討し、以下の点を明ら かにした1。

雁木通りの成立過程は、2 類型に分けられる。

(1)城下町建設と同時期に、碓木通りが建設された場合には、藩命 により、屋敷地に政策的に建設され、その後も通路機能が確保 された。
(2)城下町建設に遅れて 17 世紀中頃以降には、本来建設が禁じられ ていたはずの公儀地である道路上に睢木通りが建設された。公 儀地に建設されていた雁木通りは、19 世紀以降、占有化された 例が多い。いっぽう高田では、公儀地であった倠木下が私有地 化されたにも関わらず、町の共同体的意識により ${ }^{2}$ 通路機能が 確保された。

さらに近代以降の碓木通りの整備過程については、

(1)明治初期においては、公有地における雁木通りが整備され、通 路機能が確保された。膺木通りの公共的性格を行政が認めたた めである。

(2)その後私有地における雁木通りが整備されたものの、後に占有 化され、通路機能が損なわれた例がある。

雁木通りは、明治末期の大火や戦災、戦後の道路拡幅を契機とし て、衰退・消滅した例が多い。

本稿においては、难木通りが建設された代表的な城下町を事例に、 䧹木通りの通路幅、雁木先の孫庇や水路、看板など、㕍木通りの空 間を構成した要素について、各地に残された文書・絵図などを基に 検討する。 


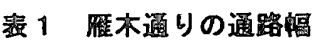

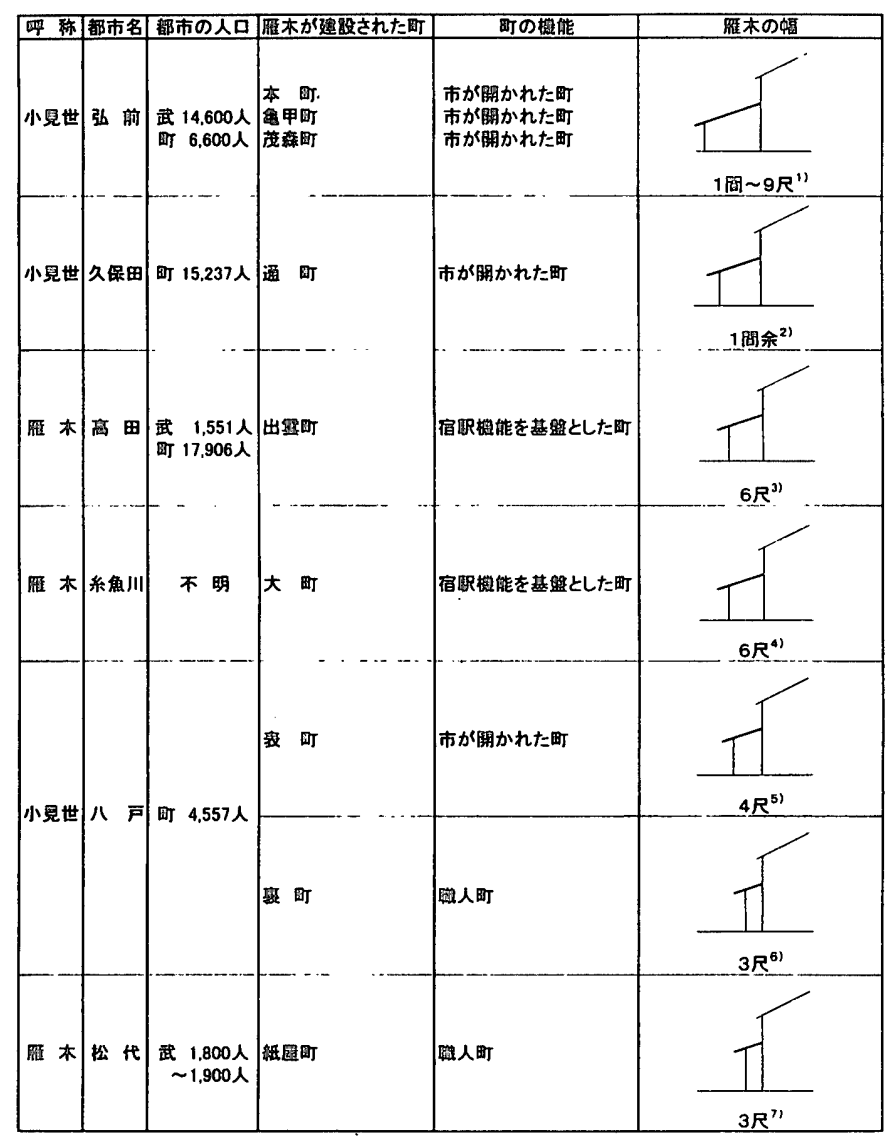

注番号は、根执となる资・史料を示す。1)『奥民図集』(『青森県立図書館 郷土双書五』青森県立図書館、1973 年)。2)『東遊雑記』(大藤時彦編『東 遊雑記 奥羽・松前巡見私記 東洋文庫 27』平凡社、1964 年。）3）『家作 画図入』上越市立高田図書館㨆原文庫蔵。4）『町年奇御用留帳』個人藏。 系魚川市役所編『系魚川市史 4』系魚川市役所、1979 年に一部所収。5).6) 前田利見『八戸藩史料 全』八戸郷友会、1929 年所收の文政 12 年 (1829)の 大火後の『家作制限』。7) 享和 13 年の記録（個人藏）太田博太郎『信激の 民家』長野県文化財保護協会、1976 年所収。都市人口は、㕍木の幅を示寸記 録の年代に近いものを記した。また町が町人の人口を、武が武家の人口を 示す。引用文献 弘前・久保田は、原田伴彦・西川幸治螎『日本の市街古 図【東日本編】解説』(鹿島研究所出版会、1973 年)。高田は、『高田市史』 1914 年。八戸は、高島成侑・三浦忠司『南部八戸の城下町』伊吉書院、19 83 年。松代は、米山一政「城下町をたずねて 20 松代」 1976 年。

\section{II. 䬺木通りの幅}

雁木通りの幅を表 1 に示す。これによると雁木通りの幅を決定し た要因は、以下の 2 点を指摘できる。

(1)雁木通りが建設された場所の機能との関係

弘前と久保田の小見世は日市が開かれた町に形成され、幅は 1 閒 を越え、幅広であった。久保田城下の様子を描いた文化文政期 (1804 〜1829）『秋田風俗絵巻』 ${ }^{3}$ にれれ゙、小見世前に設けられた仮設店 舗とともに小見世下で商品売賏する様子が描かれている(図 1)。八 戸の表町は廿三日町・十三日町・三日町など、多くの町で定期市が 開かれており、文政 12 年（1829）の大火後の『家作制限』 ${ }^{4}$ によれ

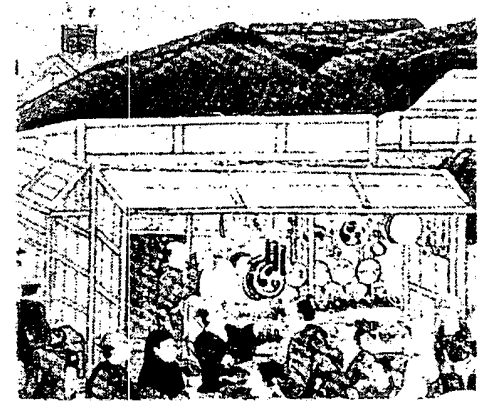

图 1 『秋田風俗䑪巻』にみる小見世下の商品売買

ば、藩は小見世の幅を 4 尺と定めた。この大火は、同史料によれば、 八戸開府以来の大火とされ、小見世の幅は大火後の家作制限の一環 として定められた。系薢川の宿駅機能を基盤に成立した大町と、高 田城下の南に位置する出雲町の㕍木の幅は 6 尺であった。出雲町は 伝馬町であったことから、隺木下が馬の荷物の積み下ろしなどに利 用されていたものと考えられる。

松代は、享保 13 年 (1728) の紙屋町の記録に5、

五間三尺町幅、右町幅之内六尺がんぎ下

とあり、紙屋町においては、道幅 5 間 3 尺の内、6 尺を㕍木通りの 敷地とした。

東西に延びる紙屋町通りの北側に位置する、18 世紀末から 19 世 紀初めにかけて建てられた相沢家と、通りの南側に位置し、幕末頃 に建てられた柿崎家に㳊、建築当初から、それぞれ 3 尺幅の嚾木が 確認される ${ }^{6}$ 。

よって幕末において矤、紙屋町通りの両側に 3 尺の幅をもつ难木 通りが建設されていた。紙屋町は、紙すき業を生業とした職人町で あった ?。さらに八戸の裹町は、大工・鍛冶などが居住する職人町 であり、文政 12 年 (1829) の大火後、藩は小見世の幅を 3 尺と定め た ${ }^{8}$ 。

以上のように雁木通りの通路幅は、市が開かれた町が最も広く、 宿駅機能を基盤とした町が続き、職人町は最も狭い。 (2)都市の人口との関倸

雁木通りの通路幅は、人口の多い方が広い傾向にある。これは人 口が多い方が、雁木通りにおける人々の往来が活発であったためで あろう。そのため、市が開かれた八戸の表町より、宿駅機能を基盤 に成立した高田の出雲町の方が、幅広の㕍木通りが建設されたもの と考えられる。

\section{III. 矤应の設置}

雁木先には、公儀地である道路上にもかかわらず、孫庇が張り出 すなど私的に利用されていた。ここでは道路上に張り出した孫庇な どの実態を明らかにする。

1) 孫庇の設置状況

a) 米沢における板庇の設置

米沢では、『石田名助記録』9 ${ }^{9}$ 享和 3 年（1803）2 月条によれば、 公儀地である道路上に，3 尺 1 寸 5 分 (半間) の幅ではみ出してい た小間屋通りの存在が知られ、さらに同記録には、

附、板底壱尺七寸王分二ト污平常䀣置候八用捨，御上御通行之節八 相はつすへき事 
とあり、道路上の小間屋先には、孫庇が設けられ、藩主が通行する 際には、取り払われた。通行の妨げとなったためであろう。

b) 系魚川における小庇の設置

文化 6 年（1809）2月 29 日の町年寄の申渡には ${ }^{10} 、$

町々小庇の儀，仰せ渡されの儀，承知つかまつり候へども，四

十物師ども日受けに相なり候ては，難渋つかまつり候間，何と

ぞ庇の儀, 御免なし下され候様願ひ申し出で候

とある。小庇とは，䧹木先の孫庇のことであり，「四十物師」とは， 有屋である。魚に日があたって腐ることを防ぐために，雁木先に小 庇を設けていたことが分る。

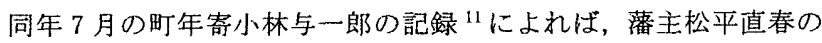
初入国に備えて，

前々归被仰渡候, 四十物師共商売方二寄小底之義八, 勿論, (中略) 残占須取片付置候様被仰渡候

とあり，肴屋の陮木先には小庇が設けられ、その撤去を藩が指示し た。藩主入国の際の通行の妨げとなったためであろう。

c) 長岡における小雁木の設置

享保年間（1716～1735）の記録には ${ }^{12} 、$

肴屋・青物屋八水取扱候二付、小かんき御免之事卜アリ

とある。肴屋と青物屋に限っては、小雁木（雁木先の孫庇に庇柱を 立てたもの）の設置を藩が許可した。店先における商品の加工・販 売に利用されたものである。

さらに降雪期の城下の様子を描いた安政 3 年 (1856)の『雪之図絵 巻』には、幕末において下級武家地が町人地化した同心町における 雁木先の小雁木が描かれ、小雁木下には、野菜などが置かれ，売買 される様子が描かれる ${ }^{13}$ 。

\section{2)採庇設置の要因}

以上のように、孫庇は職種によって設置が許可される場合など、 原則的には、条件付きではあるものの、公儀地である道路上への張 り出しが認められた。これは雁木通り同様、公儀地である道路上へ の張り出しを、藩が追認した結果と考えられる。

\section{IV. 雨落・水路の設置}

雨落は建物の雨水処理などに利用されるため深さが浅く、水路は それ以外の用途にも利用され、石皘などで作られ深さが深い。

1) 雨落・水路の設置状況

a)弘前における小見世先の水路

天明 8 年 (1788) 刊『奥民図急』には，本町の商家に扮ける落し 式の小見世の椂相が描かれている。商家の小見世の前には，降雪期 の雪捨てに利用されたと思われる幅広の水路が設けられている ${ }^{14}$ 。

b)八戸における小見世先の水路

文政 12 年（1829）の大火後には、それまで表町の道路の片側に しかなかった小見世前の水路を、防火用水としての効果を上げるた ぬ、両側に設沙たとされる。この水路は、慶応元年（1865）には、 裹町の片側の小見世先にも引かれた。水路は、表町の廿八日町・十

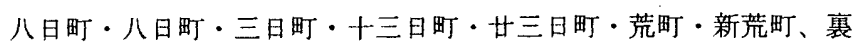
町の十六日町・六日町・朔日町に引かれた。よって幕末においては、 表町のほぼ全域と裏町の一部において、小見世先に水路が設けられ ていた ${ }^{15}$ 。 c)山形（現在の山形市）における雁木先の水路

幕末の城下の様子を描いた『湯殿山道中版画』16によれば、小間 屋先に水路が描かれている。

d) 糸魚川における雁木先の雨落

文化 13 年 (1816) には雁木先の雨落が確認できる。この雨落は、 文化 13 年 (1816) の大火後の町並整備にともない整備されたもので ある ${ }^{17}$ 。

\section{2) 雨落・水路設置の要因}

雄木先の雨落・水路は、难木の雨水処理ならびに降雪期における 積雪の処理や防火用水など様々な目的で設置されたものである。

\section{V. 建具の設置}

1) 建具の設置状況

a)弘前の戸障子

小見世先の建具については、宝暦 8 年（1758）の記録によれば、 当時、小見世柱には、吹雪を防ぐため冬期間に限り、採光用の雨障 子（油紙を貼った障子）をはった戸障子がはめられていた。天明 8 年（1788）『奥民図䱊』の插し絵にも、薬種店の前に設けられた小見 世柱の間には戸障子がはめられ、障子には大きく「薂種」と書かれ ている ${ }^{18}$

b) 黒石の戸障子

仲町に現存する宝暦 13 年（1763）に建築された高橋家には、小見 世柱の間に戸障子が設けられている ${ }^{19}$ (図 2 )。黑石では小見世先の 戸障子はてしとみ」と呼ばれる。

c) 長岡の落し板

幕末の城下の様子を描いた『懁旧歳記』 ${ }^{20}$ によれば、雁木柱の間 に落し板がはめられている様子が描かれている（図 3 ）。

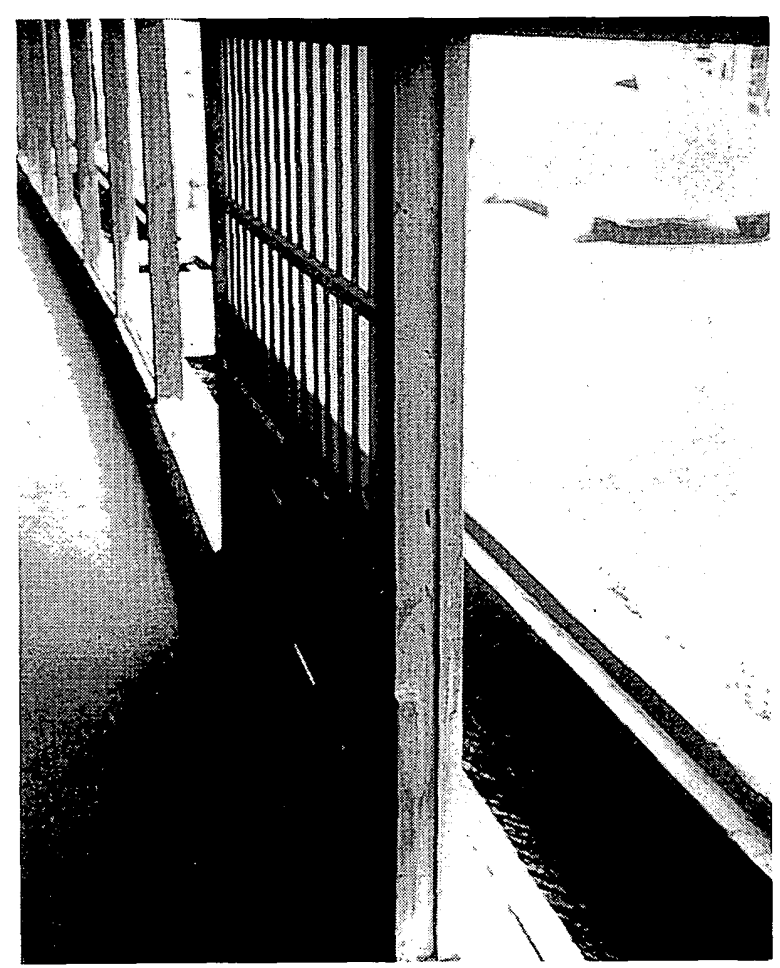

图 2 黒石のしとみ 

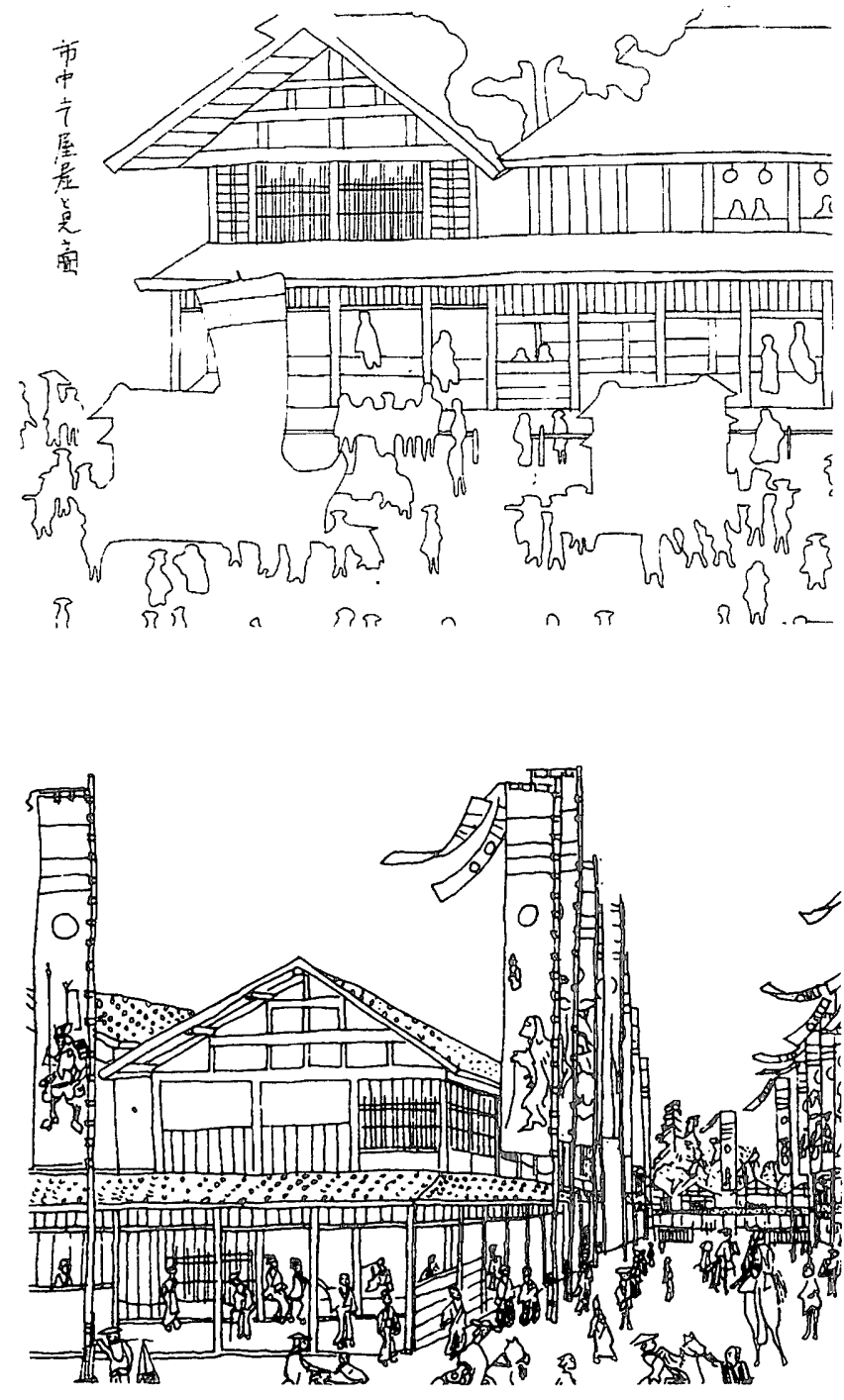

图3長岡における躣水先の落し板

\section{2)建具などの設置要因}

弘前・黑石の戸障子は上戸・下戸にわかれ、上戸には採光用の雨 障子が入れられていた。いっぽう長岡では、建具が入らず、㕍木柱 に溝を掘って板を落し込んだ。いずれも道路から雁木内に雪が入る ことを防ぎ、安全な歩行空間を確保するためのものである。

\section{VI. 筞板}

\section{a) 米沢における小間屋の看板}

米沢は、小間屋に設けられた看板の設置も規制の対象であった。 まず『石田名助記録』 21 安永 8 年（1779）条には、

来ル五日駿河守様御着之筈二候（中略）ひさしの儀八かんばん共二 取不申候

とある。けひさ」については小間屋先の板庇の可能性が高い。また 米沢新田藩主上杉勝承の城下通行に際しては、看板は取り払わなく てよいとされた。よって看板は、小間屋柱に取り付けられ、道路上 に張り出していたものと考えられる。

さらに同書享和 3 年（1803）2 月条によれば、小間屋部分の看板
について、

看板相立候事 道奉行迄願上壳弘候内可相立候事

但、御上御通行之節八可相仕超候事

とある。藩主の城下通行の際には、看板が取り払われた。

同書文化元年 (1804) 条には、

右八何年中何売買何レ之訳を以致置候哉相印

(中略)

一、看板何之売弘

右八何年中归相立侯哉相印

とあり、看板の設置状沉を調べるよう、藩が検断に指示した。その 返答として、東町の検断石田吉三朗の同書同年 4 月 4 日条によれば、

一、三間囲込 酒幄小嶋弥一郎

一、小閒屋之内、酯ノ方三尺鋪理 同人

(中略)

一、看板 酒・年 同人 何年中引相立候哉 覚無御座段申 事二御座候

何年中ヨ相立假哉 覚無御座段申事二御座候

一 看板 蛉そく"みそ 小間物 植木彦右兵衛

一、酱油・ミそ 看板 鈴木久五郎右八天明六年中道奉行所一伺 之上相立申候 且御上御通行之節八取不申様場所御差図を 受相立置申候的御座候

とあり、酒・みそ・酱油・ろうそくを扱う店が看板を出していたこ とが確認できる。また薄主通行の際にも藩の許可を得て、看板を取 り払わなくてよい場合引あった。

b) 弘前における小見世先の看板

弘前の小見世先の看板については，文化 10 年 (1813) の記録によ れば，小見世柱には，家業や借家人の名前が書かれた看板が取り付 けられていた ${ }^{22}$ 。

以上のように雁木柱には看板が設けられ、看板に榢嶪などが書 かれていた。米沢では、全ての商家に看板があったわけではなく、 趣向品や生活必需品なじを売る店に設置されていた。

\section{VIII定期市と踓水}

a) 米沢における定期市上小間屋の縁板

米沢では、江戸中期になると六歳市が廃れ、盆・正月と十月に日 市が立つようになった。十月の日市は、元和年間 (1613〜1617)に 六町が伝馬・徒夫役を㳊めるかわりに認められたものであった。日 市の開催に際し、『石田名助記録』文化 13 年（1816）11月 2 日条に よれば、

組頭中

右申渡候所喜左衛門又小間屋無之与申、源右衛門縁板無之与申 三尺迄右二付無拠入工遣ならし入遣侯事 源右衛門無之与申三 尺迄 右二付無拠大工遣ならし入遣侯事朔日二宿場罷越四軒二而 間合申由且又喜左衛門見世一用立不申段申二付延引致候事 とあり、「右申渡候所」とは、日市の開催淮備を示し、その一環とし て小閒屋のない場所に小間屋の建設を指示した。また喜左衛門宅で は、金銭的な目途が立たず小間屋の建設を延期したとある。また源 右衛門宅においては縁板の張り出しが 3 尺とある。『石田名助記録』 享保 2 年（1803）条では、小間屋の幅は 3 尺 1 寸 5 分であることか ら、小間屋下には、その幅に合わせて縁板が張りだされていたもの 


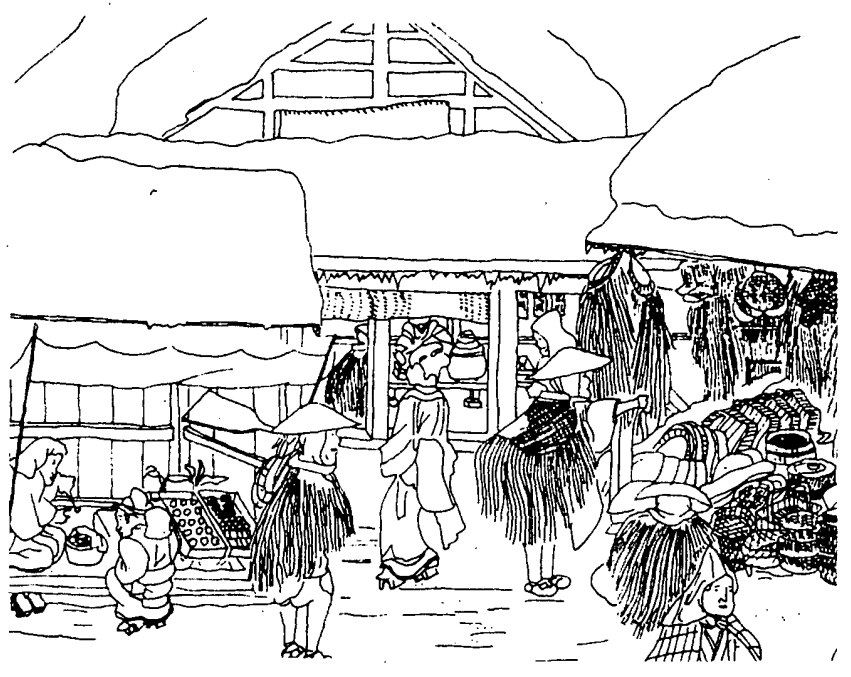

图4長岡における定期市の粎相

と考えられる。この縁板は、日市の際、商品の売買などに利用され たものであろう。

b) 長岡における定期市と隺木下の売台

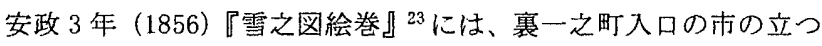
日の様相が描かれる(図 4)。裏町の㕍木通りは、公儀地である道路 上に建設され、市の際には、雁木下に商品を置く台が設けられ、雁 木通りも商品売買の場として利用された。以上のように雁木通りは、 公儀地である道路上にも関わらず、定期市の商品売買など、商業機 能を有していた。

\section{V西. おわりに}

以上を総括する。雁木通りの幅は建設された場所によって異なり、 市が開かれた町が、宿駅機能を有した町や職人町よりも広かった。 これは雁木通りが、単なる歩行者用の通路として利用されるだけで なく、18 世紀後半以降、市の開催場所としても利用されるなど、商 業活動の場であったためである。また市日の際には、㕍木下に商品 を売るための台などが設けられる場合もあった。雄木先には、公儀 地である道路上にも関わらず、孫庇や看板が設けられ、㕍木先の道 路上には、售木の雨水処理のための雨落や、消雪などにも利用され る水路が整備された。

以上のように雁木下の空間は、通路以外にも多様な機能をあわせ もっており、この多様性は、私の中から公共の空間が、あるいは公 の中から私有の空間が創出されるなど、公と私の微妙なバランスの 上に成立した赝木通りの特質である ${ }^{24}$ 。

注）

1 菅原邦生・波多野純『近世にお汀万䧹木通りの建設整備過程』日 本建築学会計画系論文集 494 号、1997 年 4 月。菅原邦生・波多野 純『近代に扮汀る雁木通りの整備過程と衰退過程』日本建築学会計 画系論文集 506 号、1998 年 4 月。(以上は日本工業大学教授波多野 純氏との共同研究）。菅原邦生『近世おける碓木通りの権利形態と利 用実態』日本建築学会計画系論文集 559 号、2002 年 9 月、『近代に おける䧹木通りの権利形態と利用実態』日本建築学会計画系論文集
567 号、2003 年 5 月がある。

2 注 1 前掲『近世における雁木通りの建設整備過程』pp221～228。 3 秋田県立博物館蔵。

4 高島成侑・三浦忠司『南部八戸の城下町』伊吉書院、1983 年 p168 ならぴに、前田利見『八戸藩史料 全』八戸郷友会、1929 年所収、 p564。文政 12 年（1829）の大火後の家作制限。「表町建揚十四 尺 前面柾にて怼斗营 小見世四尺」。

5 浦野氏蔵。太田博太郎『信濃の民家』長野県文化財保護势会、p486、 1976 年所収。

6 前揭『信濃の民家』pp $480 \sim 483$ 。

7 前揭『信濃の民家』 $\mathrm{p} 448$ 。

8 文政 12 年（1829）の大火後の家作制限。「裹町建揚十二尺 小 見世三尺」。

9『石田名助記録』享和 3 年 (1803) 条(『米沢市史 資料篇 3 近 世史料 $2 』 1984$ 年)。

10 系魚川市役所『系魚川市史 3 系魚川市役所、1978 年所収。 11 『糸魚川市史資料篇 1 文書編』系魚川边役所、1986 年所收。 12 長岡市史編集委員会近世史部会編『長岡市史双書 No. 23 長岡藩 政史料集 (4) 長岡平藏收集長岡藩史料』(長岡市、1992 年)、 $\mathrm{p} 60$ 。 13 注 1 前掲『近世における倠木通りの建設整備過程』pp221～228。 14 注 1 前揭『近世における㕍木通りの建設整備過程』pp221 228。 15 注 3 前提『南部八戸の城下町』、p 323 。

16 文化文政期（1804～1829）『湯殿山道中版画』（山形県立博物館 藏『江戸時代図誌 第 8 巻 奥州道二』筑摩書房、p127、1977 年に一部所収)

17 注 1 前掍『近世における雁木通りの建設整備過程』pp 221 228。 18 注 1 前揭『近世における㟁倠木通りの建設整備過程』pp221２28。 19 鳴海静蔵『黒石の小見世について』黒石商工会議所商業活性化委 員会、1992 年ほか。

20 『懐旧歳記』(『日本都市生活史料集成五城下町篇耐』学習研 究、1976 年所収、p516〜 563)。長岡藩士であった小川当知（善右 衛門）が実見実写により描いた絵図である。

21 注 9 前揭所収。

22 注 1 前掲『近世におけ坆不通りの建設整備過程』pp221～228。 23『雪之図絵巻』(吉田光邦編『江戸時代図誌 第 13 巻 北陸道二』 筑摩書房、p155、1977 年)に一部所収。

24 近年难木通りを生かした町づくりが盛んになってきている。例え ば幅についてみると、新潟県上越市高田や新潟県系魚川市など多く の町で一律幅広にとる傾向がある。商店街の人通りに対忘するため と考えられるが、近年の経済情勢悪化の中、商店街の人通りは当初 の計画を下回り、町の機能に応じた幅となるようエ夫する必要があ る。それが引いては生活空閒の延長としての僱木通りの保存につな がるものと考えられる。いっぽう青森県黒石市は、仲町を中心に小 見世通りの保存整借が進められ、江户期以来の小見世の幅を踏襲し て抢り、注目に值する。

（2003年 4 月 10 日原稿受理，2003年10月15日採用決定） 